УДК 616.12-089:616-007-053.1+616-053.81+616-008.1

\title{
Предиктори погіршення функціонального стану у дорослих із вродженими вадами серця у віддаленому післяопераційному періоді
}

\author{
Лебідь І. Г.
}

\author{
ДУ «Науково-практичний медичний центр дитячої кардіології такардіохірургії МОЗ України» (Київ)
}

\begin{abstract}
Дорослі з вродженими вадами серця (ВВС) мають добрі показники в ранньому післяопераційному періоді, проте питання віддаленого післяопераційного періоду потребують додаткового вивчення.

Мета роботи - виявити предиктори погіршення функціонального стану у дорослих із ВВС шляхом оцінки якості життя (ЯЖ) та фізичної працездатності (ФП) на прикладі пацієнтів після операції легеневого аутографта (ОЛА).

Матеріали та методи. 3 01.01. по 31.12.2016 було обстежено 46 дорослих віком понад 18 років: гр. А n=22 після ОЛА: гр. A1 n=8, 36\% з NYHA I; гр.A2 n=14, 64\% з NYHA II-III), гр. В n=24 здорових.

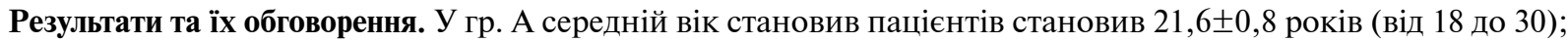
чоловіків було $\mathrm{n}=14,63,6 \%$; у гр. В $-22,7 \pm 1,3$ років (від 18 до 28), чоловіків $\mathrm{n}=14 ; 58,3 \%$. Тест шестихви-

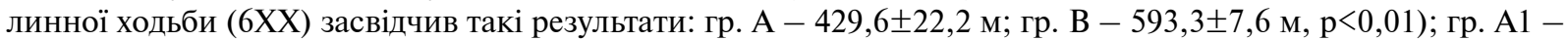
$533,8 \pm 26,7$ м, гр. А2 - 377, $1 \pm 20,6$ м (p<0,01). В оперованих обох груп на етапі II САТ становив $153,8 \pm 6,0$ та

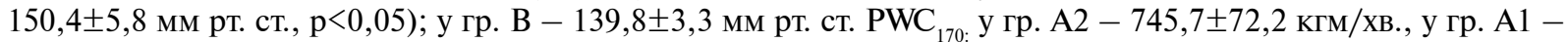

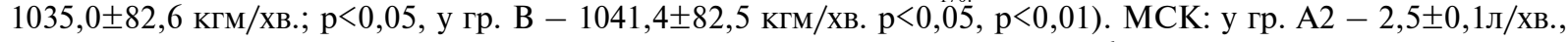

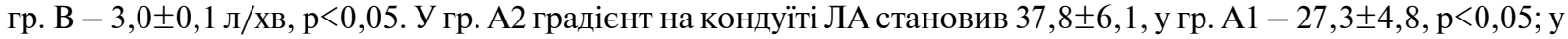

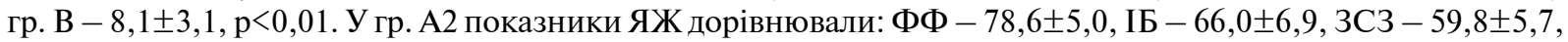

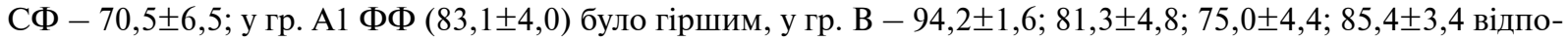
відно, $\mathrm{p}<0,05$.
\end{abstract}

Висновки. Дорослим після хірургічної корекції ВВС необхідно проводити дослідження ФП з використанням запропонованого методу та оцінювати ЯЖ за стандартними методиками.

Ключові слова: хірургія вроджених вад серия, дорослі, функціональний стан.

Щорічне збільшення кількості дорослих із ВВС потребує переходу до стандартизованого обстеження та ведення таких пацієнтів $[1,3,11,12]$. Загальна кількість пацієнтів з такими аномаліями, які досягнуть дорослого віку, наразі складається з хворих, прооперованих із приводу ВВС, а також тих, хто не потребує оперативної корекції існуючих вад [3, 5, 12]. Особливою когортою дорослих із вродженими аномаліями є пацієнти з повторними хірургічними втручаннями, де існують показання до повторних реоперацій унаслідок погіршення ступеня серцевої недостатності $(\mathrm{CH})$, а також загальний функціональний клас дорослих із вродженою патологією серця $[6,12,15]$. Оцінка стану серцево-судинної системи всіх дорослих пацієнтів із ВВС тільки в стані спокою не дозволяє виявити приховані прояви СН або підвищення ії ступеня. Прогресування СН зі зниженням толерантності до фізичного навантаження (ТФН) підвищує ризик несприятливого прогнозу та потребує більш раннього виявлення, до клінічних проявів декомпенсації $[2,4,5]$. Пацієнти 3 ВВС мають добрі показники в ранньому післяопераційному періоді, однак питання якості та тривалість життя, критерії оцінки толерантності до фізичного на- вантаження у віддаленому післяопераційному періоді потребують додаткового вивчення [1, 3, 5, 11, 12].

Мета роботи - виявити предиктори погіршення функціонального стану В дорослих із вродженими вадами серця та магістральних судин шляхом оцінки якості життя та толерантності до фізичного навантаження на прикладі спостереження за пацієнтами 3 аортальною патологією після операції легеневого аутографта.

Матеріали та методи. 31996 по 2002 рр. у ДУ «Національний інститут серцево-судинної хірургії імені М. М. Амосова НАМН» та з 2003 по 2015 рр. у ДУ «Науково-практичний медичний центр дитячої кардіології та кардіохірургії МОЗ України» операцію легеневого аутографта (ОЛА, трансплантація власного клапана легеневої артерії в аортальну позицію) було виконано 200 пацієнтам. Середній вік пацієнтів на момент операції становив $12,3 \pm 8,4$ років (від 1 міс. до 54 років). Вік на час виконання становив: до 5 років $-\mathrm{n}=48 ; 24 \%$; від 6 до 10 років $-\mathrm{n}=37 ; 18,5 \%$; від 11 до 17 років $\mathrm{n}=82 ; 41 \%$; старше 18 років $-\mathrm{n}=33 ; 16,5 \%$. 301.01 .2016 року по 30.12.2016 року було обстежено 46 послідовних дорослих пацієнтів у віці старше 18 років. Усі пацієнти 
були розділені на дві групи: до групи А увійшли 22 пацієнти з ВВС, яким була виконана ОЛА, контрольну групу (групу В) склали 24 практично здорових дорослих. Усім пацієнтам було проведено клініко-анамнестичне обстеження з оцінкою скарг, реєстрацією прийому препаратів, занять спортом, контролем частоти серцевих скорочень (ЧСС) та артеріального тиску (АТ), було оцінено функціональний клас СН за NYHA. Дистанція 426-550 м за результатами тесту 6XX відповідала ФК I за NYHA; 301-425 м - ФК II; 151-300 м - ФК III; 150 м і менше - ФК IV [2, 4]. Ехокардіографія виконувалась на ультразвуковому апараті Philips iE-33 (США), 3 використанням датчика X5-1, електрокардіограма у 12 відведеннях - на апараті Schiller AT-102 (Швейцарія) за стандартними загальноприйнятими методиками [7, 10]. Оцінка якості життя проводилася з використанням тесту SF-36 [11].

Оцінку толерантності до фізичного навантаження проводили з використанням тесту 6XX та запропонованим нами методом визначення фізичної працездатності у дорослих із ВВС [4, 5]. Розрахунок навантаження при запропонованому нами методі степергометричного варіанту проводився в підрахунку кількості підйомів на сходинку за хвилину $(\mathrm{n}=\mathrm{W} / \mathrm{p}$ h 1,33$)$, де $\mathrm{W}$ - потужність, кг* м/хв.; $\mathrm{p}$ - маса тіла, кг; $\mathrm{h}$ - висота сходинки, м; n - кількість підйомів за хвилину; 1,33 коефіцієнт, що дозволяє враховувати роботу, виконану при спуску зі сходинки. Показник максимального споживання кисню (МСК) розраховувався за формулою $\mathrm{MCK}=1,7 * \mathrm{PWC}_{170}+1240[2,4,5]$.

Статистичний аналіз виконано 3 використанням пакета програм Statistica 6 (Stat Soft Inc., США) та прикладної програми Microsoft Excel. Дані представлено у вигляді середнього значення (М) та похибки середньої величини (m). При нормальному розподілі вибірки для статистичної перевірки використовувався t-критерій Стьюдента. Якщо досліджувані вибірки не підпорядковувалися нормальному розподілу, використовувався непараметричний критерій Манна-Уїтні. Відмінності оцінюваних показників вважалися статистично значущими при $\mathrm{p}<0,05$. Оцінку ступеня впливу факторних ознак проводили за показником відношення ризиків при достовірному довірчому інтервалі $95 \%$.

Результати та їх обговорення. У групі А ( $\mathrm{n}=22)$ середній вік пацієнтів склав $21,6 \pm 0,8$ років (від 18 до 30 років), чоловіків було $n=14 ; 63,6 \%$, жінок $-n=8 ; 36,4 \%$. Віддалений післяопераційний період у даної групі склав 5,8土1,7 років. У 7 (31\%) пацієнтів відмічалися скарги на задишку при фізичному навантаженні, 11 (50\%) знаходилися на медикаментозній терапії (інгібітори ангіотензин-перетворюючого ферменту). У 2 (9\%) дорослих після ОЛА виявлено порушення ритму серця (надшлуночкова екстрасистолія), 4 (18\%) пацієнти займалися спортом. У групі А ОЛА була єдиним хірургічним втручанням у 11 (50\%) хворих. За функціональним класом СН пацієнти розподілені у такий спосіб: NYHA $\mathrm{I}-\mathrm{n}=8 ; 36 \%$; NYHA II $-\mathrm{n}=13$; $59 \%$; NYHA III $-\mathrm{n}=1$; $5 \%$. У групі В $(\mathrm{n}=22)$ середній вік склав $22,7 \pm 1,3$ років (від 18 до 28 років), чоловіків було $\mathrm{n}=14 ; 58,3 \%$, жінок $-\mathrm{n}=10 ; 41,7 \%$. Усі пацієнти даної групи на момент огляду скарг не висували, препаратів не приймали, 6 (25\%) пацієнтів систематично займалися спортом. Достовірних розбіжностей за віком, вагою, ростом між основною та контрольною групою виявлено не було $(\mathrm{p}>0,05)$.

Аналіз ЯЖ показав достатньо добрі показники 3 основних дослідних критеріъв. Так, ми не виявили достовірних розбіжностей у пацієнтів групи А за поєднаними показниками фізичного компонента здоров'я (ПП ФКЗ $(50,2 \pm 1,9)$ та психічного компонента здоров'я (ПП ПК3) $(48,3 \pm 2,4)$ порівняно з контрольною групою $(53,6 \pm 1,7$ та 48,5 $\pm 2,4$ відповідно, $\mathrm{p}>0,05)$. За оцінкою базових шкал у вигляді рольового функціонування, зумовленого фізичним станом (РФ-ФС), інтенсивності болю (ІБ), загального стану здоров'я (3С3), життєвій активності (ЖА), соціального функціонування (СФ), рольового функціонування, зумовленого емоційним станом (РФ-ЕС), психічного здоров'я (ПЗ), достовірних розбіжностей серед пацієнтів обох груп виявлено не було $(\mathrm{p}>0,05)$. У групі А показник шкали, що відображає фізичне функціонування (ФФ) $(80,2 \pm 1,9)$, був достовірно нижчим порівняно з аналогічним показником у групі В $(94,3 \pm 1,6, \mathrm{p}<0,05)$, але це не вплинуло на поєднаний показник фізичного компонента здоров'я у прооперованих хворих.

Тест 6XX у групі А пацієнти пройшли достовірно

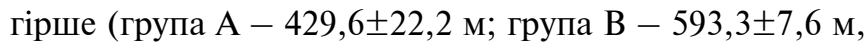
$\mathrm{p}<0,01)$. У пацієнтів після ОР вихідна ЧСС була достовірно вищою порівняно з групою здорових

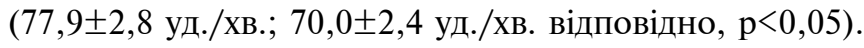
Для виявлення чинників низької толерантності додатково група А залежно від ступеня СН була розподілена на 2 підгрупи (підгрупа A1 - 8 хворих, з них 6 осіб чоловічої статі, з NYHA I; підгрупа А2 - 14 хворих, з них 8 чоловіків, з NYHA II-III). Основні клініко-інструментальні характеристики дорослих, які ввійшли в дослідження, наведено в табл. 1. У групі Al, за даними тесту 6XX, незважаючи на добрі результати відповідно до NYHA I, пацієнти пройшли достовірно коротшу дистанцію $(533,8 \pm 26,7$ м) порівняно зі здоровими дорослими групи В $(589,2 \pm 6,1$ м, $<<0,05)$. Пацієнти групи A2 пройшли достовірне меншу дистанцію $(377,1 \pm 20,6)$ порівняно к із хворими групи A1, так і з дорослими контрольної групи $(\mathrm{p}<0,01)$.

При оцінці толерантності до фізичного навантаження, відповідно до запропонованого способу, вихідна ЧСС була достовірно вищою в групі А2 ( $79,1 \pm 3,8$ уд./ хв.) порівняно 3 контрольною групою $(71,6 \pm 2,2$ уд./ хв., $\mathrm{p}<0,05)$ за відсутності достовірних відмінностей при оцінці АТ. На етапі I навантаження ЧСС досто- 
Таблиця 1

Клінічні та інструментальні показники у пацієнтів, залучених у дослідження

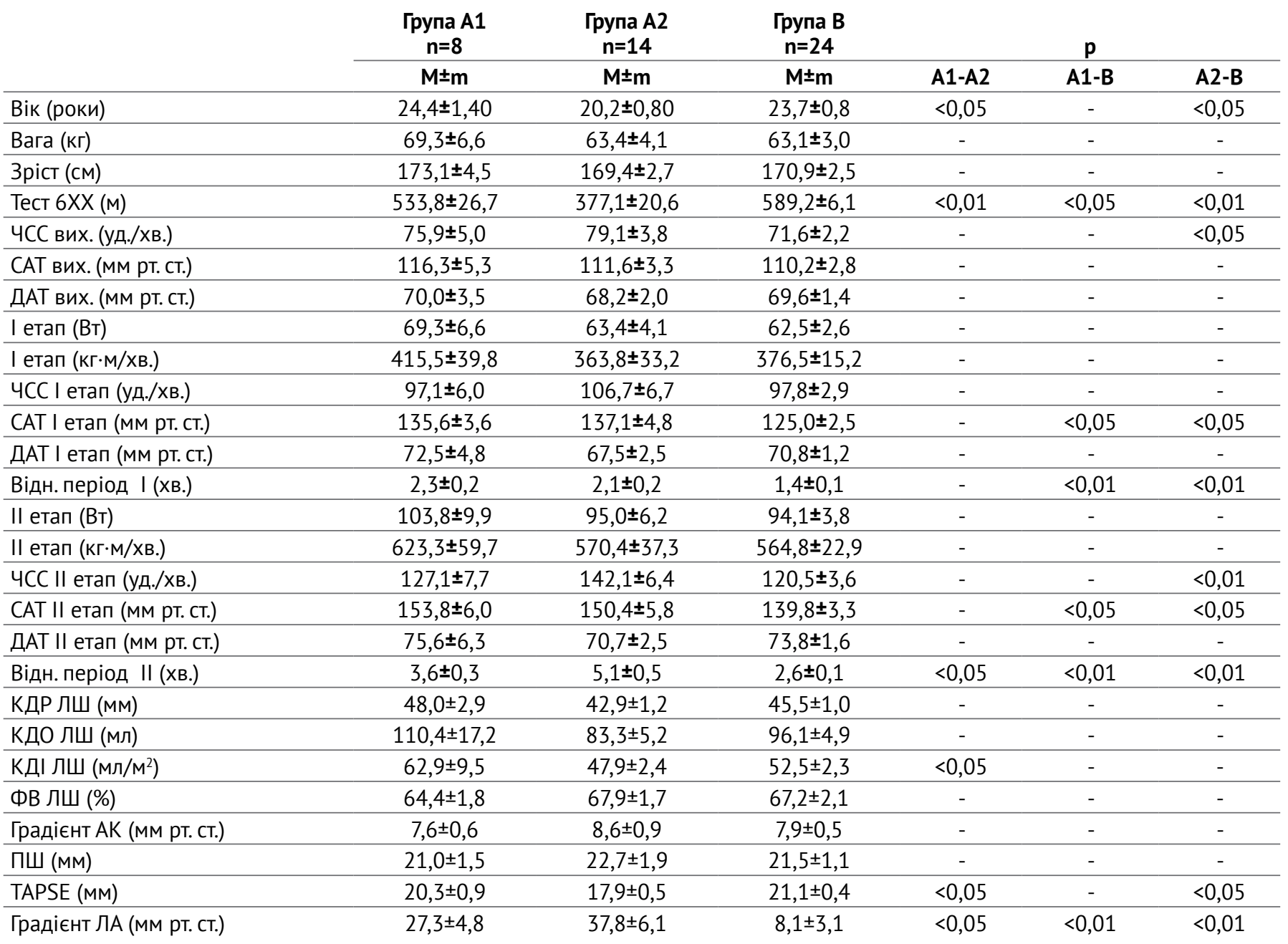

САТ - систолічний АТ, ДАТ - діастолічний АТ, відн. період - відновлювальний період

вірно не відрізнялася в обох групах прооперованих пацієнтів порівняно з контрольною групою, однак САТ мав достовірно вищі показники $(135,6 \pm 3,6$ мм рт. ст. у групі A1 $(\mathrm{p}<0,05)$ та $137,1 \pm 4,8$ мм рт. ст. $(\mathrm{p}<0,05)$ у групі А2) порівняно з групою здорових дорослих

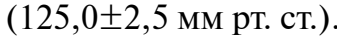

На етапі II навантаження ЧСС була достовірно вищою у прооперованих пацієнтів групи А2 $(142,1 \pm 6,4$ уд./хв., $\mathrm{p}<0,01)$ порівняно з показниками у контрольній групі (120,5 $\pm 3,6$ уд./хв.). В оперованих хворих обох груп на даному етапі САТ був достовірно вищим $(153,8 \pm 6,0$ мм рт. ст.; $150,4 \pm 5,8$ мм рт. ст. відповідно, $\mathrm{p}<0,05)$ порівняно з групою здорових дорослих (139,8 $\pm 3,3$ мм рт. ст.). Діастолічні показники АТ на обох етапах навантаження серед всіх прооперованих дорослих груп A1 та А2 не мали достовірних відмінностей порівняно з аналогічними показниками контрольної групи. Відновлювальний період після фізич- ного навантаження на етапі I в обох групах A1 та A2 (2,3 $\pm 0,2$ хв.; $2,1 \pm 0,2$ хв. відповідно) був достовірно подовжений порівняно з дорослими у групі В $(1,4 \pm 0,1$ хв., $\mathrm{p}<0,01)$. Дослідний показник на етапі II в обох групах (3,6 $\pm 0,3$ хв.; $5,1 \pm 0,5$ хв. відповідно) аналогічно був достовірно довшим порівняно з групою В $(2,6 \pm 0,1$ хв., $\mathrm{p}<0,01)$, але у групі А2 була отримана достовірна ризниця даного показника з групою $\mathrm{A} 1(\mathrm{p}<0,05)$.

Толерантність до фізичного навантаження у пацієнтів групи А2 відмічалася як достовірно знижена порівняно з групами A1 та В. Так, показники фізичної працездатності $\left(\mathrm{PWC}_{170}\right)$ в абсолютному значенні та в перерахунку на вагу $\left(\mathrm{PWC}_{170} / \mathrm{Kг}\right)$ в групі A2 $(745,7 \pm 72,2$ кг м/ хв. та $12,0 \pm 0,8$ кг м/хв/кг) були достовірно нижчими порівняно з групою A1 $(1035,0 \pm 82,6$ кг м/хв. та $14,1 \pm 1,1$ кг м/хв./кг; $\mathrm{p}<0,05)$ та групою здорових дорослих - $(1041,4 \pm 82,5 \mathrm{\kappa г} \mathrm{м/хв.} \mathrm{та} 16,5 \pm 1,1 \mathrm{\kappa г} \mathrm{м/Хв./}$ кг, $\mathrm{p}<0,05, \mathrm{p}<0,01$ відповідно). Під час фізичного на- 
вантаження абсолютний показник MCK у групі А2 $(2,5 \pm 0,1$ л/хв.) мав достовірно нижчі значення порівняно з групою В $(3,0 \pm 0,1$ л/хв., $p<0,05)$. Даний показник,

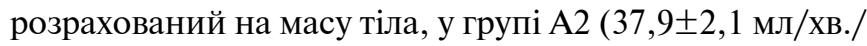
кг), був достовірно меншим порівняно з аналогічними показниками у групах A1 $(43,6 \pm 2,6$ мл/хв./кг; $\mathrm{p}<0,05)$ та В $(48,6 \pm 2,0$ мл/хв./кг, $p<0,01)$ відповідно. У заключному висновку в групі А незадовільна адаптація до фізичного навантаження виявлена практично у половини прооперованих пацієнтів - 45\% ( $\mathrm{n}=10$ : в групі $\mathrm{A} 1$ $\mathrm{n}=2$, у групі A2 n=8); задовільна - у $23 \%(\mathrm{n}=5$; в групі $\mathrm{A} 1 \mathrm{n}=2$, у групі A2 n=3), добра - у $32 \%$ (n=7; у групі A1 $\mathrm{n}=4$, у групі A2 n=3). Нормотонічна реакція АТ на навантаження фіксувалась у 16 (73\%) прооперованих дорослих (у групі A1 n=8, у групі $\mathrm{A} 2 \mathrm{n}=8$ ), гіпертонічна у 3 (13\%) (усі пацієнти тільки в групі А2), дистонічна - у 3 (13\%) (у групі A1 n=1, у групі A2 n=2).

Оцінка морфологічних та функціональних показників серцево-судинної системи за даними ехокардіографії у пацієнтів після ОЛА порівняно зі здоровими дорослими наведена в табл. 1. Привертає увагу відсутність достовірних розбіжностей показників лівого шлуночка (ЛШ): кінцевого діастолічного розміру (КДР) та кінцевого діастолічного об'єму (КДО) ЛШ в дослідних групах $(\mathrm{p}>0,05)$. Індексований показник кінцевого діастолічного об'єму (кінцевий діастолічний індекс (КДІ ЛШ) у групі А1 був достовірно вищим порівняно з аналогічним показником у групі А2, однак не виходив за межи вікової норми). Функція ЛШ за показниками фракції викиду (ФВ) ЛШ не мала достовірних відмінностей у хворих після ОЛА та у групі здорових дорослих. Достовірно значущих розбіжностей градієнта трансаортального кровотоку через нео-АК після ОЛА в обох групах порівняно з контрольною групою виявлено не було (p>0,05).

При аналізі розмірів та функції ПШ було виявлено достовірно низькі показники руху кільця трикуспі-

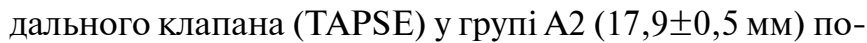
рівнянні з групами A1 (20,3 $\pm 0,9$ мм) та B $(21,1 \pm 0,4$ мм $)$ $(\mathrm{p}<0,05)$, що опосередковано може свідчити про зниження систолічної функції ПШ. Важливо відмітити відсутність розбіжностей у розмірах ПШ у досліджуваних групах дорослих. В обох групах оперованих хворих показник транспульмонального кровотоку на кондуїті ЛА був достовірно вищим при порівнянні з контрольною групою. Так, у групі А2 градієнт на кондуїті ЛА був достовірно вищим (37,8 66,1 мм рт. ст.)

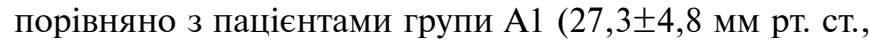
$\mathrm{p}<0,05)$ та групи В $(8,1 \pm 3,1$ мм рт. ст., $\mathrm{p}<0,01)$, в гру-

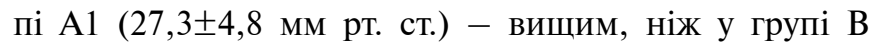
$(8,1 \pm 3,1$ мм рт. ст., $p<0,01)$.

Якість життя, як важливий критерій оцінки дорослих після ОЛА, показав значні розбіжності серед пацієнтів у групі А1 та А2 порівняно з контрольною групою (рис. 1).
Так, у групі А2 показники, що відображають ФФ $(78,6 \pm 5,0)$, ІБ $(66,0 \pm 6,9), 3 \mathrm{C} 3(59,8 \pm 5,7)$ та СФ $(70,5 \pm 6,5)$, були достовірно гіршими порівняно з аналогічними показниками групи В $(94,2 \pm 1,6 ; 81,3 \pm 4,8$; 75,0 $0 \pm 4,4 ; 85,4 \pm 3,4$ відповідно, $\mathrm{p}<0,05)$. У пацієнтів групи А1 ЯЖ була значно кращою, що відобразилося у погіршенні тільки за одним показником фізичного функціонування $(83,1 \pm 4,0)$ порівняно 3 дорослими контрольної групи $(\mathrm{p}<0,05)$. Розбіжності між групами A1 та А2 були відмічені лише за показником соціального функціонування $(90,6 \pm 3,9$ та 70,5 66,5 відповідно, $\mathrm{p}<0,05)$. Решта показників, шо відображають ЯЖ, достовірно не відрізнялися ( $>0,05)$.

Підсумовуючи результати оцінки ЯЖ, зазначимо, що при аналізі поєднаних показників фізичного компонента $(54,1 \pm 1,9)$ та психічного компонента здоров'я $(52,5 \pm 3,4)$ у групі A1 достовірних розбіжностей 3 контрольною групою дорослих $(53,6 \pm 1,7$ та 48,5 $\pm 2,4$ відповідно, p>0,05) виявлено не було (рис. 2). Однак у групі А2 отримано достовірно гірші дані поєднаного показника фізичного компонента $(48,0 \pm 2,5)$ при відсутності достовірних розбіжностей за даними поєднаного показника психічного компонента здоров'я $(45,9 \pm 3,0)$ порівняно з групою В. Така динаміка цілком відповідає отриманим даним тесту оцінки толерантності до фізичного навантаження.

Ступінь компенсації серцевої діяльності у пацієнтів із ВВС у спокої не завжди дозволяє виявити приховані зміни та прогресування СН. Згідно з рекомендаціями ведення дорослих із ВВС усім пацієнтам після карді-

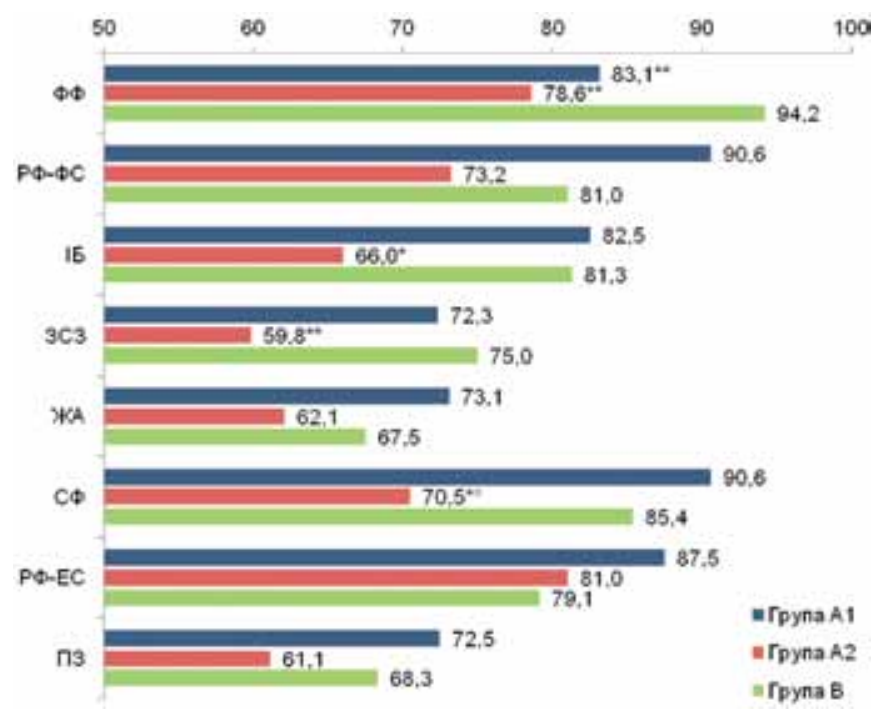

Рис. 1. Порівняльна оцінка ЯЖ за допомогою опитувальника SF-36 пацієнтів, залучених у дослідження. Різниця показників статистично значуща порівняно з такими у здорових осіб: * $p<0,05$; ** $p<0,01$. Різниия показників статистично значуща порівняно з такими у прооперованих хворих підгрупи A1-A2: ${ }^{\circ} p<0,05$ 


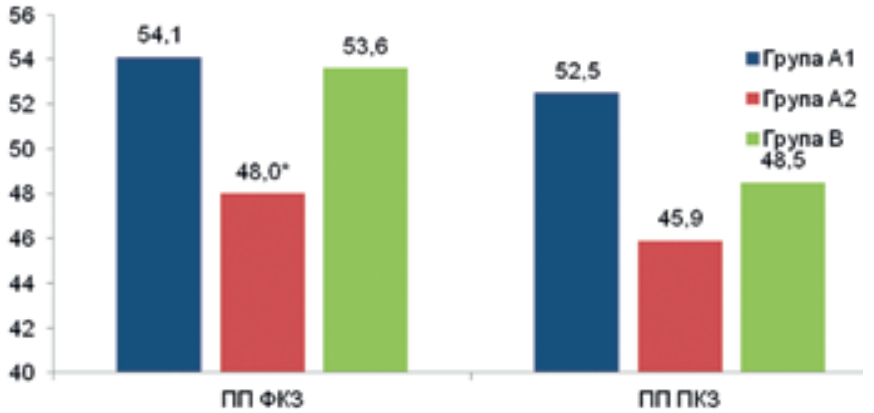

Рис. 2. Порівняльна оцінка підсумовуючих показників ЯЖ за допомогою опитувальника SF-36 серед пацієнтів, залучених у дослідження. Різниця показників статистично значуща порівняно з такими у здорових осіб: * $p<0,05$

охірургічної корекції, за відсутності протипоказань, необхідно проводити дослідження з дозованим фізичним навантаженням, яке є високоінформативним методом об'єктивізації таких проблем [12]. Запропонований нами спосіб для визначення толерантності до фізичного навантаження у дорослих пацієнтів із ВВС $€$ простим і доступним для клінічного використання, не потребує додаткового обладнання і може виконуватися навіть лікарем із невеликим досвідом роботи $[4,5]$. Доведено, що взаємовідношення між ЧСС і потужністю навантаження має лінійний характер, що дозволяє сформувати лінійну екстраполяцію при розрахунку PWC $_{170} 3$ використанням двох менш виражених навантажень [2]. Між потужністю навантаження і ЧСС лінійна залежність зберігається у молодих людей у діапазоні 170 уд./хв., а при перевищенні цього порогу зазначена залежність втрачається [2, 4, 8, 13].

Протезування АК легеневим аутографтом дозволила зробити великий крок уперед у лікуванні дітей та молодих дорослих із вродженою патологією АК та кореня аорти $[9,13,14]$. Безпосередні результати ОЛА дуже добрі та обнадійні. Летальність у ранньому післяопераційному періоді становить, за різними даними, від 0,5 до 4,2\% [13-15]. Проте у віддаленому періоді формуються анатомічні особливості та ускладнення, такі, як формування аневризми кореня неоаорти, посилення ступеня аортальної недостатності, формування обструкції у вихідному тракті правого шлуночка (ПШ) $[13,15]$. Крім суто хірургічних ускладнень, останній часом приділяється багато уваги оцінці якості життя, толерантності до фізичного навантаження, можливості занять спортом, плануванню вагітності у хворих, які досягли дорослого віку $[6,11,14]$.

Отримані дані свідчать про добрі післяопераційні результати у віддаленому післяопераційному періоді після заміни АК легеневим аутографтом за даними ехокардіографічного обстеження у спокої. Виявлені нормальні показники розмірів лівого шлуночка (ЛШ) та його скоротливості, відсутність значушого градієнту на нео-АК демонструють адекватні гемодинамічні зміни, які були метою ОЛА у хворих на вроджену ваду АК. Однак протокольне дослідження стану серцево-судинної системи з дозованим фізичним навантаженням у частини пацієнтів після ОЛА показало достовірне зниження основних функціональних показників серцевої діяльності, які відображають знижену фізичну працездатність $\left(\mathrm{PWC}_{170}\right.$ та перерахований на вагу $\left.\mathrm{PWC}_{170}\right)$.

В обох групах, незалежно від ступеня СН, було виявлено достовірно виражений приріст САТ при відсутності достовірних змін ДАТ в оперованих пацієнтів на обох етапах навантаження порівняно 3 групою зорових дорослих (на етапі 1: у групі A1 $135,6 \pm 3,6$ мм рт. ст., у групі А2 - 137, $1 \pm 4,8$ мм рт. ст.,

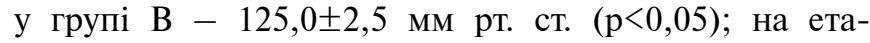
пі 2: $153,8 \pm 6,0$ мм рт. ст., $150,4 \pm 5,8$ мм рт. ст., $139,8 \pm 3,3$ мм рт. ст. $(\mathrm{p}<0,05)$ відповідно). Така динаміка, на наш погляд, викликана підвищенням жорсткості стінки кореня нео-АК при достатньо адекватній функції легеневого аутографта в аортальній позиції.

Аналіз клініко-анамнестичних факторів, яки впливають на зниження функціонального стану та прогноз СН у пацієнтів після ОЛА, засвідчив достовірно молодший вік хворих із NYHA II-III порівняно з пацієнтами із NYHA I та здоровими дорослими. Це свідчить, що ОЛА, виконана у підлітковому або в дорослому віці, має кращі прогностичні характеристики, ніж коли термін операції припадає на дитячий вік $[13,14]$. Статеві розбіжності у нашому дослідженні підтвердили перевагу чоловіків у структурі вродженої аортальної патології, яким була виконана ОЛА, однак залежності статі та ії впливу на перебіг СН у післяопераційному періоді нами виявлено не було.

Важливо відмітити, що у групі пацієнтів після ОЛА половина пацієнтів $(\mathrm{n}=11,50 \%)$ перенесли додаткові хірургічні та інтервенційні втручання. Вісім $(72,7 \%)$ пацієнтів мали попередні втручання, $5(45,4 \%)$ - повторні. У групі пацієнтів із NYHA II-III був достовірно більшим середній показник кількості втручань $(2,1 \pm 0,3)$ порівняно $з$ дорослими після ОР без ознак $\mathrm{CH}(1,3 \pm 0,2, \mathrm{p}<0,05)$. На нашу думку, додаткові кардіохірургічні втручання (як попередні, так і повторні) впливають на віддалений період з можливістю погіршення функціонального стану та зниження толерантності до фізичного навантаження, тому обов'язково мають бути враховані у таких хворих.

Аналіз стану серцево-судинної системи традиційно проводиться на підставі оцінки функції ЛШ $[2,7,9]$. Функція ПШ ускладнена анатомічними особливостями і не завжди враховується при стандартному обстеженні [7]. При оцінці групи оперованих хворих із NYHA II-III було виявлено достовірно вищі показники транспульмонального кровотоку на кондуїті ЛА та достовірно знижені показники руху кільця трикуспі- 
дального клапана (TAPSE) при відсутності розбіжностей у розмірах ПШ порівняно з пацієнтами без ознак $\mathrm{CH}$ та здоровими дорослими. Такі результати показують зниження систолічної функції ПШ, що пояснює подовження відновлювального періоду та більш низьку фізичну працездатність, знижений показник МCK, який характеризує фізичну аеробну працездатність та є об’єктивним критерієм оцінки дієздатності у віддаленому періоді, показником загального стану, тяжкості післяопераційних ускладнень [2, 8, 13, 15]. Таким чином, отримані дані адаптації до фізичного навантаження у прооперованих дорослих пацієнтів свідчать про необхідність більш детального обстеження таких пацієнтів не тільки у спокої, а й при фізичному навантаженні.

\section{Висновки}

1. Предикторами погіршення функціонального стану у дорослих із вродженими вадами серця та магістральних судин $€$ погіршення ступеня компенсації серцевої діяльності, яка у спокої не завжди дозволяє виявити прогресування серцевої недостатності, тому таким пацієнтам у віддаленому післяопераційному періоді необхідно проводити дослідження 3 дозованим фізичним навантаженням із використанням запропонованого методу визначення ФП у дорослих з ВВС.

2. У дорослих із ВВС функціональний клас серцевої недостатності (за NYHA II та більше) асоціюється з низькою переносністю фізичного навантаження, зниженням показників якості життя, що пов'язано зі здоров'ям, факторів, що відповідають за оцінку фізичного компонента.

3. Низька фізична працездатність у віддаленому післяопераційному періоді у певних пацієнтів після операції легеневого аутографта проявляється зниженими показниками PWC $_{170}$, MCK і є наслідком перенесених додаткових втручань, зумовлена достовірно вищими показниками обструкції на кондуїті легеневої артерії та зниженням руху кільця трикуспідального клапана (TAPSE) як ознаками зниження систолічної функції правого шлуночка.

Автор заявляє про відсутність конфлікту інтересів.

\section{Література}

1. Хирургическое лечение болезней системы кровообращения в Российской Федерации (2010-2014 гг.) / Бокерия Л. А., Ступаков И. Н., Гудкова Р. Г. И до. // Вестник Росздравнадзора. - 2016. - № 1. - С. 63-69.

2. Белоцерковский 3. Б. Сердечная деятельность и функциональная подготовленность у спортсменов: норма и атипичные изменения. - М. : Советский спорт. 2012. $-547 \mathrm{c}$.
3. Качество жизни после хирургического лечения врожденных пороков сердца у взрослых пациентов / Крупянко С. М., Милиевская Е. Б., Ермоленко М. Л. и др. // Бюллетень НЦССХ им. А. Н. Бакулева РАМН Сердечно-сосудистые заболевания. - 2014. - Т. 15. №. 2. - C. 26-35.

4. Спосіб визначення фізичної працездатності у дорослих з вродженими вадами серця / Лебідь І. Г., Разінкіна А. О., Климишин Ю. І. та ін. // Патент на корисну модель № 112844 UA, А61B 5/02 (2006.01) №u 201608045; заявл. 20.07.2016; опубл. 26.12.2016, Бюл. № 24.

5. Тести з фізичним навантаженням у пацієнтів із вродженими вадами серця. Практичний посібник / Лебідь І. Г., Ханенова А. А., Лєбєдь Є. І. та ін. - Дніпро : Середняк Т. К., 2017. - 52 с.

6. Фізичний складник реабілітаційного потенціалу дорослих із вродженими вадами серця у відділені терміни після операційного спостереження / Лисунець О. М., Ханюкова І. Я., Ткаченко Ю. В. та ін. // Український вісник медико-соціальної експертизи. 2014. - № 4. - С. 22-26.

7. Рыбакова М. К., Митьков В. В., Балдин Д. Г. Эхокардиография от М. К. Рыбаковой. - М. : Издательский дом Видар, 2016. - 600 с.

8. Сергиенко Л. П. Непрямые методы определения максимального потребления кислорода (обзор) // Слобожанський науково-спортивний вісник. - 2015. - № 1 (45). - C. 109-122.

9. Непосредственные результаты модифицированной операции Росса / Чернов И. И., Козьмин Д. Ю., Макеев С. А. и др. // Патология кровообращения и кардиохирургия. - 2016. - Т. 20 (№ 1). - С. 12-18.

10. Хэмптон Д. ЭКГ в практике врача (2-е издание). - М. : Медицинская литература. - 2013. - 400 с.

11. Якість життя у пацієнтів із вродженими вадами серця. Практичний посібник / І. Г. Лебідь, Н. М. Руденко, А. Ю. Сидоренко [та ін.]. - Київ : Вид. НПМЦДКК, 2016. $-49 \mathrm{c}$.

12. ESC Guidelines for the management of grown-up congenital heart disease (new version 2010) / Baumgartner H., Bonhoeffer P., De Groot N. M. et al. // European heart journal. - 2010. - Vol. 23. - P. 2915-57.

13. Becker O. Gesundheitsbezogene Lebensqualität und funktionelles Outcome bei Patienten nach Ross-Operation im Vergleich zur Normbevölkerung (Health-related quality of life and functional outcome in patients after Ross surgery compared to the norm population). -2016 . $-118 \mathrm{p}$.

14. Long-Term Follow-Up After the Ross Procedure: A Single Center 22-Year Experience / Schneider A. W., Putter H., Klautz R. J. et al. // The Annals of Thoracic Surgery. 2017. - Vol. 103 (6). - P. 1976-1983.

15. Current status of the Ross procedure in aortic valve surgery / Vojáček J., El-Hamamsy I., Ondrášek J. et al. // Cor et Vasa. - 2017. - Vol. 59. - P. e71-e76. 


\title{
Predictors of functional state degradation in adults with congenital heart disease at late follow up period
}

\author{
Lebid I. H. \\ $\mathrm{Gl}$ «The scientific practical children's cardiac center» (Kyiv)
}

Adults with congenital heart disease (CHD) have good follow-up in the early postoperative period, but late postoperative period require further examination.

The purpose of the work was to reveal predictors of a functional condition deterioration in adults with the CHD (after pulmonary autograft operation, PAO) by an estimation the quality of a life (QL) and physical working capacity (PWC).

Material and methods. From 01 Jan. to 31 Dec 2016 there were examined 46 consecutive adults elder 18 years. Gr.A $(n=22)$ patients after PAO (Gr.A1 $n=8$ with NYHA I, Gr.A2 $n=14$ with NYHA II-III), Gr.B $(n=24)$ healthy adults.

Results. In Gr.A mean age 21.6 \pm 0.8 years (from 18 to 30 years), male ( $\mathrm{n}=14 ; 63.6 \%$ ), Gr.B- $22.7 \pm 1.3$ years (from 18 to 28 years), male ( $\mathrm{n}=14 ; 58.3 \%$ ). Test 6MWT (Gr.A 429.6 $\pm 22.2 \mathrm{~m}$, Gr.B 593.3 $\pm 7.6 \mathrm{~m}, \mathrm{p}<0.01$; Gr.A1 533.8 $\pm 26.7 \mathrm{~m}$, Gr.A2 $377.1 \pm 20.6 \mathrm{~m} . \mathrm{p}<0.01)$. Second stage Systolic BP (Gr.A1 153.8 \pm 6.0 ; Gr.A2 $150.4 \pm 5.8 \mathrm{mmHg})$ Gr.B $(139.8 \pm 3.3 \mathrm{p}<0,05)$. $\mathrm{PWC}_{170}$ in Gr.A2 (745.7 $\left.\pm 72.2 \mathrm{kgm} / \mathrm{min}\right)$, Gr.A1 $(1035.0 \pm 82.6 \mathrm{kgm} / \mathrm{min} \mathrm{p}<0,05)$ and Gr.B $(1041.4 \pm 82.5 \mathrm{kgm} / \mathrm{min} \mathrm{p}<0.05$, $\mathrm{p}<0.01)$. $\mathrm{Vo}_{2}$ in Gr.A2 $(2.5 \pm 0.1 \mathrm{l} / \mathrm{min})$, Gr.B $(3.0 \pm 0.1 \mathrm{l} / \mathrm{min}, \mathrm{p}<0.05)$. In Gr.A2 gradients on PA conduit were (37.8 \pm 6.1$)$, Gr.A1 (27.3 $\pm 4.8 \mathrm{p}<0.05)$ and in Gr.B (8.1 $\pm 3.1 \mathrm{p}<0.01)$. Indexes of QoL were in Gr.A2 PF (78.6 \pm 5.0$)$, BP (66.0 \pm 6.9$)$, GH $(59.8 \pm 5.7)$ and SF (70.5 \pm 6.5$)$, in Gr.A1 PF (83.1 \pm 4.0$)$ were worse compare with Gr.B $(94.2 \pm 1.6 ; 81.3 \pm 4.8 ; 75.0 \pm 4.4$; $85.4 \pm 3.4$, respectively, $\mathrm{p}<0,05)$.

Conclusions. All patients after surgical correction of CHD are necessary to study exercise performance using the proposed method and estimate QL in late postoperative period.

Key words: congenital aortic valve, physical activity, quality of life, reconstructive surgery, adult.

\section{Предикторы ухудшения функционального состояния у взрослых с врожденными пороками сердца в отдаленном послеоперационном периоде}

\author{
Лебедь И.Г.
}

ГУ «Научно-практический медицинский центр детской кардиологии и кардиохирургии МЗ Украины» (Киев)

У взрослых с врожденными пороками сердца (ВПС) отмечаются хорошие показатели в раннем послеоперационном периоде, однако вопросы отдаленного послеоперационного периода требуют дополнительного изучения.

Цель работы - выявить предикторы ухудшения функционального состояния у взрослых с ВПС путем оценки качества жизни (КЖ) и физической работоспособности (ФР) на примере пациентов после операции легочного аутографта (ОЛА).

Материалы и методы. С 01.01. по 31.12.2016 было обследовано 46 взрослых старше 18 лет: гр. А (n=22) после ОЛА (гр. A1 n=8, 36\% с NYHA I; гр. A2 n=14, 64\% с NYHA II-III), гр. B n=24 здоровые.

Результаты и обсуждение. В гр. А средний возраст составил 21,6 $\pm 0,8$ года (от 18 до 30); мужчин было n=14;

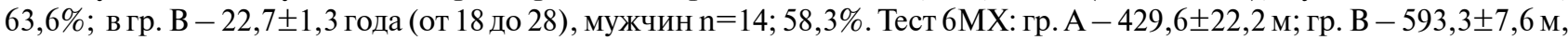

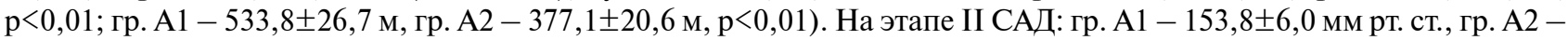

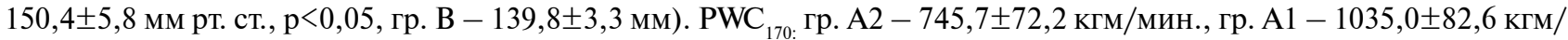

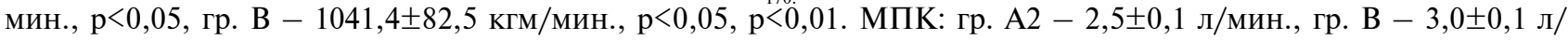

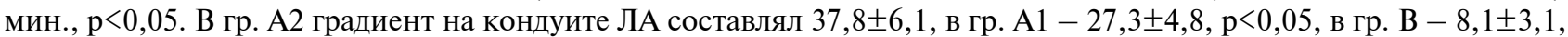

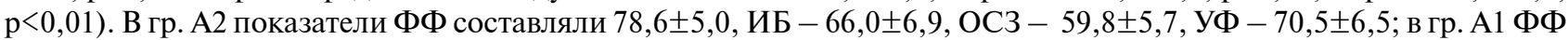
$(83,1 \pm 4,0)$ были хуже, в гр. В - 94,2 $\pm 1,6 ; 81,3 \pm 4,8 ; 75,0 \pm 4,4 ; 85,4 \pm 3,4$ соответственно, $\mathrm{p}<0,05$.

Выводы. Взрослым после хирургической коррекции ВПС необходимо проводить оценку ФР с использованием предложенного метода и оценивать КЖ по стандартным методикам.

Ключевые слова: хирургия врожденных пороков сердиа, взрослые, функциональное состояние. 